\title{
Tri-iodothyronine increases insulin-like growth factor binding protein-2 expression in cultured hepatocytes from hypothyroid rats
}

\author{
I Demori, C Bottazzi and E Fugassa \\ Istituto di Fisiologia Generale, Università di Genova, Corso Europa 26, I-16132 Genova, Italy \\ (Requests for offprints should be addressed to E Fugassa)
}

\begin{abstract}
Previous evidence suggests the existence of a thyroid hormone-IGF axis in the liver and changes in hepatic insulin-like growth factor binding protein (IGFBP) expression in rats with altered thyroid status have been previously reported.

The aim of this study was to check if the higher IGFBP-2 mRNA levels observed in liver of hypothyroid rats could be due to a direct effect of thyroid hormone on the IGFBP-2 gene. In our experiments, cultured hepatocytes isolated from normal and hypothyroid adult rats were used. Northern blot analysis revealed barely detectable IGFBP-2 mRNA in normal rat hepatocytes, but easily detectable signal in hypothyroid rat cells. Therefore, the effect of tri-iodothyronine $\left(\mathrm{T}_{3}\right)$ was investigated using cultured hepatocytes from hypothyroid rats as an in vitro model.

The IGFBP-2 message was increased in a dosedependent manner in hepatocytes cultured for 12-24 h in the presence of $\mathrm{T}_{3}$. A similar increase occurred in accu-
\end{abstract}

mulation of IGFBP-2 in the culture medium, as measured by RIA. The effect of $\mathrm{T}_{3}$ on IGFBP-2 transcript levels appeared to consist of enhanced gene transcription and was independent of ongoing protein synthesis, but it was completely abolished by the incubation of hepatocytes with insulin. The latter result confirmed the dominant role of insulin in regulating IGFBP-2 expression by cultured hepatocytes.

In vivo experiments confirmed an increase in hepatic IGFBP-2 mRNA and serum IGFBP-2 levels in hypothyroid rats and demonstrated, in addition, a significant increase in these measures in $\mathrm{T}_{3}$-treated rats.

Taken together, our in vitro and in vivo results support a role for a thyroid hormone-IGF axis in the liver and suggest that other factors, such as insulin, interact in vivo with thryoid hormone in regulating hepatic IGFBP-2 expression.

Journal of Endocrinology (1999) 161, 465-474

\section{Introduction}

The insulin-like growth factors (IGF-I and -II) are polypeptide hormones, similar in structure to proinsulin, which play important roles in cell growth and differentiation. The IGFs are found, in the circulation and in the extracellular fluids, bound to specific high-affinity binding proteins (IGFBP-1 to -6 ) that are unrelated to either type of the IGF-receptors. The IGFBPs are potent modulators of IGF actions on target cells and have been reported both to inhibit and to potentiate IGF activity (Froesch et al. 1985, Rechler 1993, Jones \& Clemmons 1995).

The components of the IGF/IGFBP system are produced by different cells and tissues, the liver being one of the major sites of synthesis. The levels of IGFBPs in serum and IGFBP mRNAs in liver are highly regulated by metabolic and hormonal factors as well as by the developmental age.

In adult rat serum, most of the IGFs circulate as a $150-\mathrm{kD}$ a ternary complex that consists of IGF-I, IGFBP-3 and an acid-labile subunit (ALS). In contrast, in fetal rat serum there are high levels of IGF-II and the most abundant binding protein is IGFBP-2 (Lund et al. 1986, Donovan et al. 1989, Ooi et al. 1990, Albiston \& Herington 1992).

In the rat, IGFBP-2 mRNA has been detected in several fetal tissues, the highest levels being in the liver (Brown et al. 1989). Although message levels are barely detectable in adult liver, relatively high levels persist in adult brain, testes, ovaries and kidney (Margot et al. 1989).

The factor(s) responsible for the regulation of IGFBP-2 mRNA within rat tissues are not well defined. Hepatic IGFBP-2 transcript is increased by hormonal and metabolic manipulation of adult animals such as fasting, hypophysectomy and diabetes (Böni-Schnetzler et al. 1989, Margot et al. 1989, Orlowski et al. 1990, Ooi et al. 1990, Tseng et al. 1992). Interestingly, the increase after hypophysectomy is not normalized by growth hormone $(\mathrm{GH})$ treatment (Margot et al. 1989, Ooi et al. 1990), suggesting a possible involvement of other hormones regulated by 
pituitary secretion. A candidate for this role could be thyroid hormone: it has been demonstrated that thyroid hormone withdrawal increases the expression of IGFBP-2, in both developing and adult rat liver (Näntö-Salonen et al. 1991, Rodriguez-Arnao et al. 1994). GH replacement in hypothyroid animals did not correct the increase in IGFBP-2 message, suggesting a possible direct regulation of this gene by thyroid hormone (Näntö-Salonen et al. 1993).

We have recently demonstrated a tri-iodothyronine $\left(\mathrm{T}_{3}\right)$-induced increase in IGFBP-4 expression in a rat hepatocyte model, in total agreement with the in vivo effects of thyroid hormone withdrawal from or administration to the rats (Demori et al. 1997). In the same experiments, we were unable to obtain evidence of an effect of $\mathrm{T}_{3}$ on IGFBP-2 expression, because of the barely detectable level of IGFBP-2 message in cultured hepatocytes from adult rats.

In the present study, we used the in vitro model of primary hepatocytes isolated from hypothyroid rats, which express high levels of IGFBP-2 mRNA, enabling us to demonstrate the direct regulation of IGFBP-2 expression by $\mathrm{T}_{3}$.

\section{Materials and Methods}

\section{Animals}

Adult male Wistar rats were rendered hypothyroid by the addition of $0.05 \%$ propylthiouracil (PTU) or $0.05 \%$ methimazole (MMI) to the drinking water from the 6th to the 15th week of age. Age-matched rats receiving regular drinking water served as controls. During the last week before being killed, groups of both hypothyroid and control rats were treated daily with i.p. injections of $\mathrm{T}_{3}$ $(15 \mu \mathrm{g} / 100 \mathrm{~g}$ body weight).

Animals were killed by cervical dislocation. Blood was collected, allowed to clot and the serum stored at $-80{ }^{\circ} \mathrm{C}$. Serum $T_{3}$ and thyroxine $\left(T_{4}\right)$ were evaluated by an enhanced chemiluminescent (ECL) enzyme immunoassay (DPC, Los Angeles, CA, USA). The limit of detection of the assay was $0.35 \mathrm{ng} / \mathrm{ml}$ for $\mathrm{T}_{3}$ and $4 \mathrm{ng} / \mathrm{ml}$ for $\mathrm{T}_{4}$.

Immediately after death of the rat, the liver was promptly removed, quickly frozen in liquid nitrogen and stored at $-80{ }^{\circ} \mathrm{C}$ until required for use.

\section{Hepatocyte primary cultures}

Male Wistar rats rendered hypothyroid by PTU administration were used to isolate hepatocytes by a standardized collagenase (type I, Sigma Chemical Co., St Louis, MO, USA) perfusion technique as previously described (Fugassa et al. 1983). Cells (viability $\geq 85 \%$ by trypan blue exclusion) were resuspended at a concentration of $5 \times 10^{5}$ cells/ml in serum-free Dulbecco's modified Eagle's medium (DMEM) supplemented with essential and nonessential amino acids, insulin $(0.1 \mathrm{U} / \mathrm{ml})$ and dexamethasone $\left(10^{-6} \mathrm{M}\right)$. Next, $8 \mathrm{ml}$ of this cell suspension were plated on collagen (type III, Sigma)-coated 100-mm plastic dishes (Costar, Cambridge, MA, USA). After 90 min, medium with unattached cells was aspirated and monolayers were exposed to DMEM containing 0.25\% BSA (fraction V, cell culture tested, Sigma). Specific experiments were begun on cultures that had been incubated for $24 \mathrm{~h}$ of adaptation to the in vitro environment (time 0$). \mathrm{T}_{3}$ (Sigma) was added to the culture medium at indicated concentrations. Insulin (Actrapid HM, Novo Nordisk, Bagsvaerd, Denmark) was added to the culture medium at the concentration of $10^{-8} \mathrm{M}$. The protein synthesis inhibitors, cycloheximide $(0.1 \mu \mathrm{g} / \mathrm{ml}$; Sigma) and anisomycin $(2.65 \mu \mathrm{g} / \mathrm{ml}$; Sigma), were added to the cultures $1 \mathrm{~h}$ before the addition of $\mathrm{T}_{3}$. The transcription inhibitor, actinomycin D (Sigma), was used at a concentration of $5 \mu \mathrm{g} / \mathrm{ml}$. PTU (Sigma) was used at a dose of $5.8 \times 10^{-9} \mathrm{M}$ (Cook et al. 1983).

Cell viability was not affected by the duration of the culture or by the addition of drugs to the medium, as checked by trypan blue exclusion test.

At the indicated times, culture medium was removed; monolayers were quickly washed twice with ice-cold sterile PBS, immediately frozen in liquid nitrogen and stored at $-80{ }^{\circ} \mathrm{C}$ until used for RNA extraction.

\section{RNA isolation}

Total RNA was prepared using acid guanidinium thyocyanate-phenol-chloroform extraction (Chomczynski \& Sacchi 1987). RNA was quantified by measuring absorbance at $260 \mathrm{~nm}$. Samples were stored at $-80{ }^{\circ} \mathrm{C}$ until required for use.

\section{cDNA probes}

The rat IGFBP-2 (Brown et al. 1989) cDNA probe was kindly provided by Dr S Shimasaki, Department of Cell Biology, The Scripps Research Institute, La Jolla, CA, USA. The human glyceraldehyde-3-phosphate dehydrogenase (G3PDH) cDNA probe was purchased from Clontech Laboratories Inc., Palo Alto, CA, USA. The rat $18 \mathrm{~S}$ rDNA probe (BamHI-HindIII fragment, Chan et al. 1984) was generously provided by Dr I G Wool, Department of Biochemistry and Molecular Biology, University of Chicago, Chicago, IL, USA. The probes were labelled to high specific radioactivity by multiprime DNA labelling systems (Amersham International plc, Amersham, Bucks, UK) using $\left[{ }^{32} \mathrm{P}\right] \mathrm{dCTP}$ (NEN Du Pont, Du Pont De Nemours GmbH, Bad Homburg, Germany; specific radioactivity $3000 \mathrm{Ci} / \mathrm{mmol}$ ).

\section{Northern blot analysis}

Total RNA $(20 \mu \mathrm{g})$ was fractionated by loading on $1 \%$ agarose gel containing $2 \cdot 2 \mathrm{M}$ formaldehyde in $20 \mathrm{mM}$ 
MOPS (pH 7.0), $5 \mathrm{mM}$ sodium acetate and $1 \mathrm{mM}$ disodium EDTA. RNA was stained with ethidium bromide to check the integrity of the samples and ensure equal loading in each lane. After transfer of the samples to nylon membrane by capillary blotting, prehybridization was performed for $2 \mathrm{~h}$ at $42{ }^{\circ} \mathrm{C}$ in a solution containing $5 \times \operatorname{SSPE}\left(1 \times \operatorname{SSPE}=0 \cdot 15 \mathrm{M} \mathrm{NaCl}-0 \cdot 01 \mathrm{M} \mathrm{NaH}_{2} \mathrm{PO}_{4}-\right.$ $1 \mathrm{mM}$ EDTA), $50 \%$ formamide, $5 \times$ Denhardt's solution, $0.5 \%$ SDS and $100 \mu \mathrm{g} / \mathrm{ml}$ denatured salmon sperm DNA (Sambrook et al. 1989). Hybridization was carried out for $20 \mathrm{~h}$ at $42{ }^{\circ} \mathrm{C}$ in fresh buffer containing the ${ }^{32} \mathrm{P}$-labelled probe. After hybridization, the filters were washed sequentially in $2 \times$ SSPE, $0 \cdot 1 \%$ SDS, $1 \times$ SSPE, $0 \cdot 1 \%$ SDS and $0 \cdot 1 \times \operatorname{SSPE}, 0 \cdot 1 \%$ SDS at $42{ }^{\circ} \mathrm{C}$, each wash lasting for $20 \mathrm{~min}$. Filters were then exposed to Amersham Hyperfilm-MP films at $-80{ }^{\circ} \mathrm{C}$ using intensifying screens.

To ensure even loading, the membranes were stripped and rehybridized with either a human G3PDH cDNA probe or a rat $18 \mathrm{~S}$ rDNA probe.

The signal intensity of the autoradiograms was quantified densitometrically using the Scion ImagePC software package. Arbitrary densitometric units were normalized to G3PDH or $18 \mathrm{~S}$ and expressed as a percentage of the control values.

\section{IGFBP-2 determination in serum and conditioned medium}

IGFBP-2 concentrations in rat serum and hepatocyte conditioned medium were measured by RIA (DSL, Webster, Texas, USA), with a limit of detection of $0.5 \mathrm{ng} / \mathrm{ml}$.

\section{Statistical analyses}

Data are presented as the mean \pm S.E.M. Statistical significance was analysed using ANOVA with the multiple group comparison test of Scheffé. Differences were regarded as significant when $P \leq 0 \cdot 05$.

\section{Results}

\section{IGFBP-2 $m R N A$ levels in cultured hepatocytes}

Hepatocytes were incubated for $24 \mathrm{~h}$ to allow adaptation to the in vitro environment, then transferred into fresh DMEM supplemented as described under Materials and Methods. At different times, total RNA was extracted and analysed for the presence of IGFBP-2 mRNA by Northern blot hybridization. As shown in Fig. 1, Northern blot analysis revealed barely detectable IGFBP-2 mRNA in normal rat hepatocytes, according to Arany et al. (1993). In contrast, when cells were prepared from PTU-treated hypothyroid rats, the IGFBP-2 message was readily detected. No direct effect of PTU on IGFBP-2 mRNA

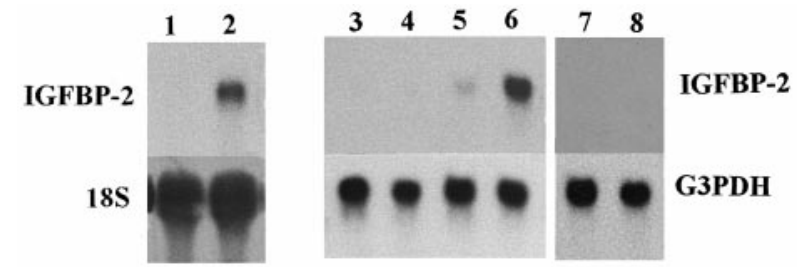

Figure 1 IGFBP-2 mRNA levels in cultured rat hepatocytes. Representative autoradiograms of Northern blots showing $1.5 \mathrm{~kb}$ IGFBP-2 mRNA, $1.3 \mathrm{~kb}$ G3PDH mRNA and $1.9 \mathrm{~kb}$ 18S rRNA. Lanes: 1 , adult rat liver; 2 , hypothyroid rat liver; 3 , adult rat hepatocytes cultured for $24 \mathrm{~h} ; 4$, adult rat hepatocytes cultured for $24 \mathrm{~h}$ in the presence of $10^{-6} \mathrm{M} \mathrm{T}_{3} ; 5$, hypothyroid rat hepatocytes cultured for $24 \mathrm{~h} ; 6$, hypothyroid rat hepatocytes cultured for $24 \mathrm{~h}$ in the presence of $10^{-6} \mathrm{M} \mathrm{T}_{3} ; 7$, adult rat hepatocytes cultured for $24 \mathrm{~h} ; 8$, adult rat hepatocytes cultured for $24 \mathrm{~h}$ in the presence of $5 \cdot 8 \times 10^{-9} \mathrm{M}$ PTU.

levels was seen when the drug was added to the culture medium of normal hepatocytes. Therefore, the effect of $\mathrm{T}_{3}$ was investigated using cultured hepatocytes isolated from hypothyroid rats.

\section{Effect of $\mathrm{T}_{3}$ on IGFBP-2 expression in cultured hepatocytes}

Figure 2 shows the characteristic $1.5 \mathrm{~kb}$ IGFBP-2 message expressed by rat hepatocytes cultured for up to $24 \mathrm{~h}$ after the first $24 \mathrm{~h}$ of adaptation to the culture conditions. It appears that IGFBP-2 mRNA levels increased with the time in culture. When $10^{-6} \mathrm{M} \mathrm{T}_{3}$ was present in the culture medium for $12-24 \mathrm{~h}$, the abundance of IGFBP-2 mRNA was significantly enhanced $(P<0 \cdot 001)$.

IGFBP-2 concentration in conditioned media of hepatocytes cultured for $12 \mathrm{~h}$ was $11.5 \pm 1.8 \mathrm{ng} / \mathrm{ml}$, and this value was increased in $10^{-6} \mathrm{M} \mathrm{T}_{3}$-treated cells $(19.7 \pm 1.7 \mathrm{ng} / \mathrm{ml}, P \leq 0.03)$, consistent with what was observed at the mRNA level.

Figure 3 shows the levels of IGFBP-2 mRNA after the addition of $\mathrm{T}_{3}$ to the culture medium to final concentrations ranging from $10^{-10}$ to $10^{-6} \mathrm{M}$. After $12 \mathrm{~h}$ of exposure, the maximal increase in IGFBP-2 mRNA levels was elicited by $10^{-6}-10^{-8} \mathrm{M} \mathrm{T}_{3}$, whereas $10^{-9}$ and $10^{-10} \mathrm{M}$ were ineffective.

Effect of cycloheximide and anisomycin on $T_{3}$-induced $I G F B P-2 m R N A$ levels in cultured hepatocytes

Hepatocytes were cultured for $12 \mathrm{~h}$ in the presence of either cycloheximide $(0 \cdot 1 \mu \mathrm{g} / \mathrm{ml})$ or anisomycin $(2 \cdot 65 \mu \mathrm{g} /$ $\mathrm{ml}$ ), which both inhibit de novo protein synthesis. The inhibitors were used at doses that did not decrease cell viability over the time of incubation, but were able to inhibit protein synthesis in cultured hepatocytes by 90-97\% (Barreca et al. 1992, Messina 1991).

As shown in Fig. 4, the presence of cycloheximide or anisomycin in the culture medium resulted in increased 
(A)

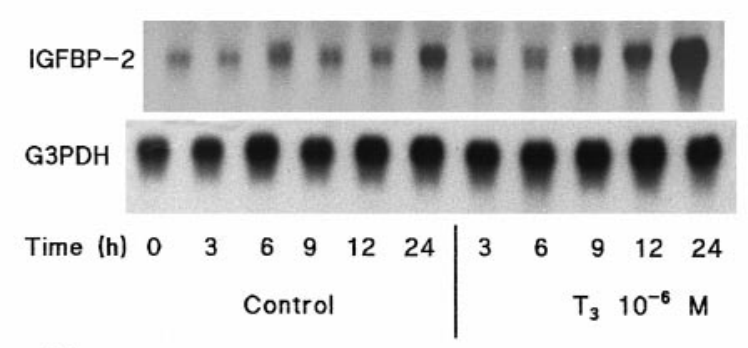

(B)

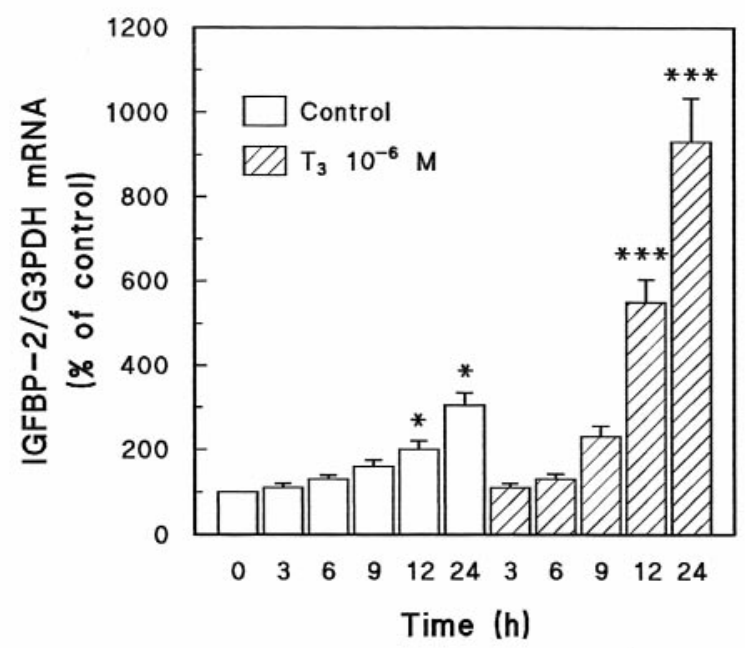

Figure 2 Time course of the $T_{3}$ effect on IGFBP-2 mRNA levels in hypothyroid rat hepatocytes cultured in the absence or presence of $10^{-6} \mathrm{M} \mathrm{T}_{3}$. (A) Representative autoradiograms of Northern blots showing $1.5 \mathrm{~kb}$ IGFBP-2 and $1.3 \mathrm{~kb}$ G3PDH mRNAs. (B) Densitometric quantification of Northern blots shown in (A) after normalization to G3PDH. Hatched bars, with $\mathrm{T}_{3}$; open bars, without $T_{3}$. Results are expressed as percentage of the control at time 0 (mean \pm S.E.M.; $n=3$ ). ${ }^{*} P<0.02$ compared with time 0 ; $* * * P<0.001$ compared with respective controls.

overall amount of IGFBP-2 mRNA, but did not affect the effect of $\mathrm{T}_{3}$ on the specific transcript.

Effect of actinomycin $D$ on $T_{3}$-induced IGFBP-2 $m R N A$ levels in cultured hepatocytes

To check the effect of $T_{3}$ on IGFBP-2 mRNA stability, hepatocytes were cultured for $12 \mathrm{~h}$ in the absence or presence of $\mathrm{T}_{3}$ to achieve the induction of IGFBP-2 mRNA, and then exposed to actinomycin D $(5 \mu \mathrm{g} / \mathrm{ml})$, a potent inhibitor of transcription, in order to evaluate IGFBP-2 mRNA decay.

As shown in Fig. 5, both control and $\mathrm{T}_{3}$-treated hepatocytes showed stable IGFBP-2 mRNA levels, even after $12 \mathrm{~h}$ of incubation with actinomycin D. Owing to
(A)
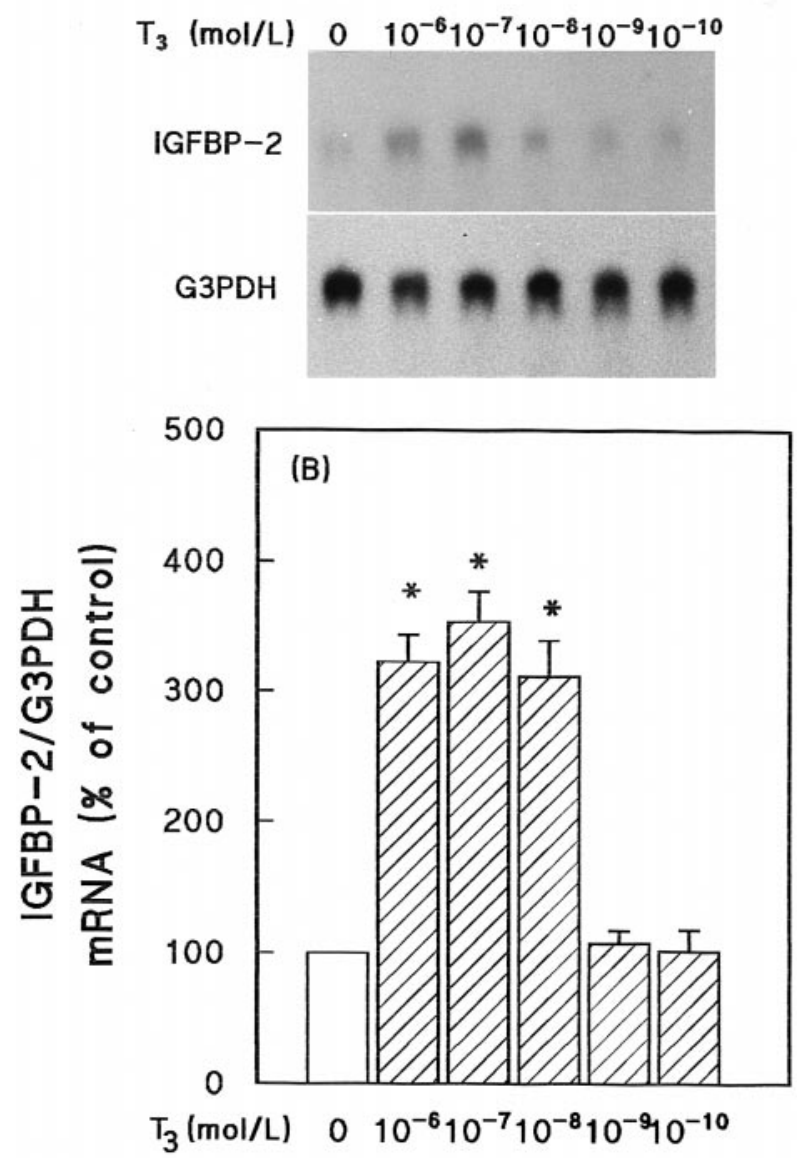

Figure 3 Dose-dependence of the effect of $\mathrm{T}_{3}$ on IGFBP-2 mRNA levels in hypothyroid rat hepatocytes cultured for $12 \mathrm{~h}$ in the absence or presence of different doses of $\mathrm{T}_{3}$. (A) Representative autoradiograms of Northern blots showing $1.5 \mathrm{~kb}$ IGFBP-2 and $1 \cdot 3 \mathrm{~kb}$ G3PDH mRNAs. (B) Densitometric quantification of Northern blots after normalization to G3PDH. Results are expressed as percentage of control (open bar) (mean \pm S.E.M.; $n=3)$. ${ }^{*} P<0.001$ compared with control.

the lack of decay of IGFBP-2 mRNA, it was impossible to evaluate its half-life and consequently the effect of $T_{3}$ on IGFBP-2 mRNA stability.

As shown in Fig. 6, the presence of actinomycin D along with $\mathrm{T}_{3}$ in the culture medium of hepatocytes cultured for $12 \mathrm{~h}$ prevented the $\mathrm{T}_{3}$-induced increase in IGFBP-2 mRNA levels, suggesting a transcriptional regulation of IGFBP-2 gene by $\mathrm{T}_{3}$.

Effect of insulin on $T_{3}$-induced IGFBP-2 $m R N A$ levels in cultured hepatocytes

It has been reported that insulin decreases IGFBP-2 mRNA levels in cultured hepatocytes (Böni-Schnetzler 
(A)

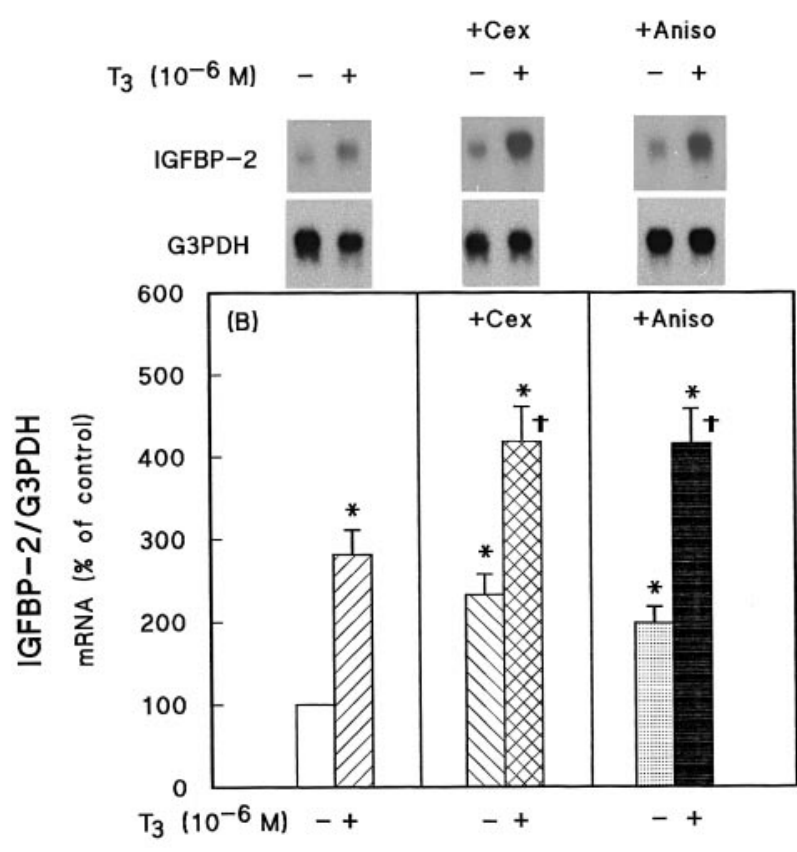

Figure 4 Effects of cycloheximide (Cex) $(0 \cdot 1 \mu \mathrm{g} / \mathrm{ml})$ and anisomycin (Aniso) $(2.65 \mu \mathrm{g} / \mathrm{ml})$ on IGFBP-2 mRNA levels in hypothyroid rat hepatocytes cultured for $12 \mathrm{~h}$ in the presence (+) or absence (-) of $10^{-6} \mathrm{M} \mathrm{T}_{3}$. (A) Representative autoradiograms of Northern blots showing $1.5 \mathrm{~kb}$ IGFBP-2 and $1.3 \mathrm{~kb}$ G3PDH mRNAs. (B) Densitometric quantification of Northern blots after normalization to G3PDH. Results are expressed as percentage of control $(\square)$ (mean \pm S.E.M.; $n=3$ ). ${ }^{*} P<0.03$ compared with control; $+P<0 \cdot 05$ compared with Cex- or Aniso-treated.

et al. 1990). We tested the effect of the pancreatic hormone on basal and $\mathrm{T}_{3}$-induced IGFBP-2 expression in our culture system. As can be seen in Fig. 7, the presence of $10^{-8} \mathrm{M}$ insulin in the culture medium for $12 \mathrm{~h}$ resulted in decreased levels of IGFBP-2 message. When insulin was present in the culture medium of hepatocytes together with $\mathrm{T}_{3}$, the stimulatory effect of the latter hormone was completely abolished.

\section{Effect of $T_{3}$ administration on IGFBP-2 expression in rat liver}

The finding that hepatic IGFBP-2 expression is enhanced in vivo by thyroid hormone withdrawal and in vitro by addition of $\mathrm{T}_{3}$ to the culture medium of hepatocytes from hypothyroid rats induced us to verify the effects of $T_{3}$ administration to both hypothyroid and euthyroid rats.

Groups of control and hypothyroid rats were injected daily with $\mathrm{T}_{3}(15 \mu \mathrm{g} / 100 \mathrm{~g}$ body weight $)$ during the last week before death.

Serum $T_{3}$ and $T_{4}$ levels of the animals are reported in Table 1. PTU treatment always resulted in lower serum concentrations of thyroid hormone with respect to controls. The same results were obtained when the rats were treated with MMI (not shown). $\mathrm{T}_{3}$ treatment induced high serum $\mathrm{T}_{3}$ concentrations, associated with low serum concentration of $T_{4}$.

Figure 8 shows that PTU-induced hypothyroidism was associated with enhanced expression of hepatic IGFBP-2 mRNA. $\mathrm{T}_{3}$ treatment decreased hepatic IGFBP-2 mRNA to about $50 \%$ of the levels of hypothyroid rat liver. When $\mathrm{T}_{3}$ was given to control rats, the hepatic IGFBP-2 signal was faint but reproducible and significantly greater compared with the undetectable signal in control livers. The changes in IGFBP-2 levels in the serum of the same rats paralleled those of the hepatic mRNA in all conditions tested (Table 2).

As shown in Fig. 9, the amount of IGFBP-2 mRNA was increased in the liver of MMI-treated hypothyroid rats compared with controls. The abundance of the IGFBP-2 transcript in the liver of $\mathrm{T}_{3}$-replaced rats was lower than that in hypothyroid animals, but higher with respect to controls. A similar pattern was observed for serum IGFBP-2 levels (not shown).

\section{Discussion}

In the rat, the IGFBPs are produced by different tissues and cell types under a complex and specific regulation by hormonal, nutritional and developmental factors. During fetal and early postnatal life, the liver produces high levels of IGFBP-2, but within the first 3 weeks after birth hepatic IGFBP-2 production strongly decreases to the barely detectable levels typical of the adult rat. It has been reported that congenital hypothyroidism delays the decline of hepatic IGFBP-2 expression after birth (Näntö-Salonen et al. 1991), and an increase in hepatic IGFBP-2 mRNA has also been observed in rats rendered hypothyroid in adulthood (Rodriguez-Arnao et al. 1994). Therefore, thyroid hormone appears to play a role in regulating hepatic IGFBP-2 production in newborn and adult rats. However, our previous attempts to demonstrate a direct effect of $\mathrm{T}_{3}$ on IGFBP-2 expression were ineffective (Demori et al. 1997).

In the present study, we have analysed the effect of $\mathrm{T}_{3}$ on hepatic IGFBP-2 expression using cultured hepatocytes isolated from hypothyroid adult rats, in which the IGFBP-2 message is easily detectable and the sensitivity to exogenous $T_{3}$ may be greater than that of cells from euthyroid animals (Mariash \& Oppenheimer 1983).

The typical $1.5 \mathrm{~kb}$ IGFBP-2 mRNA was clearly expressed by hepatocytes from hypothyroid rats cultured for up to $24 \mathrm{~h}$. The addition of $\mathrm{T}_{3}$ to the hepatocyte culture medium increased the abundance of IGFBP-2 message, to about $300 \%$ with respect to control cells. The stimulation was highly significant after $12-24 \mathrm{~h}$ of incubation with $\mathrm{T}_{3}$ in doses ranging from $10^{-8}$ to $10^{-6} \mathrm{M}$. 

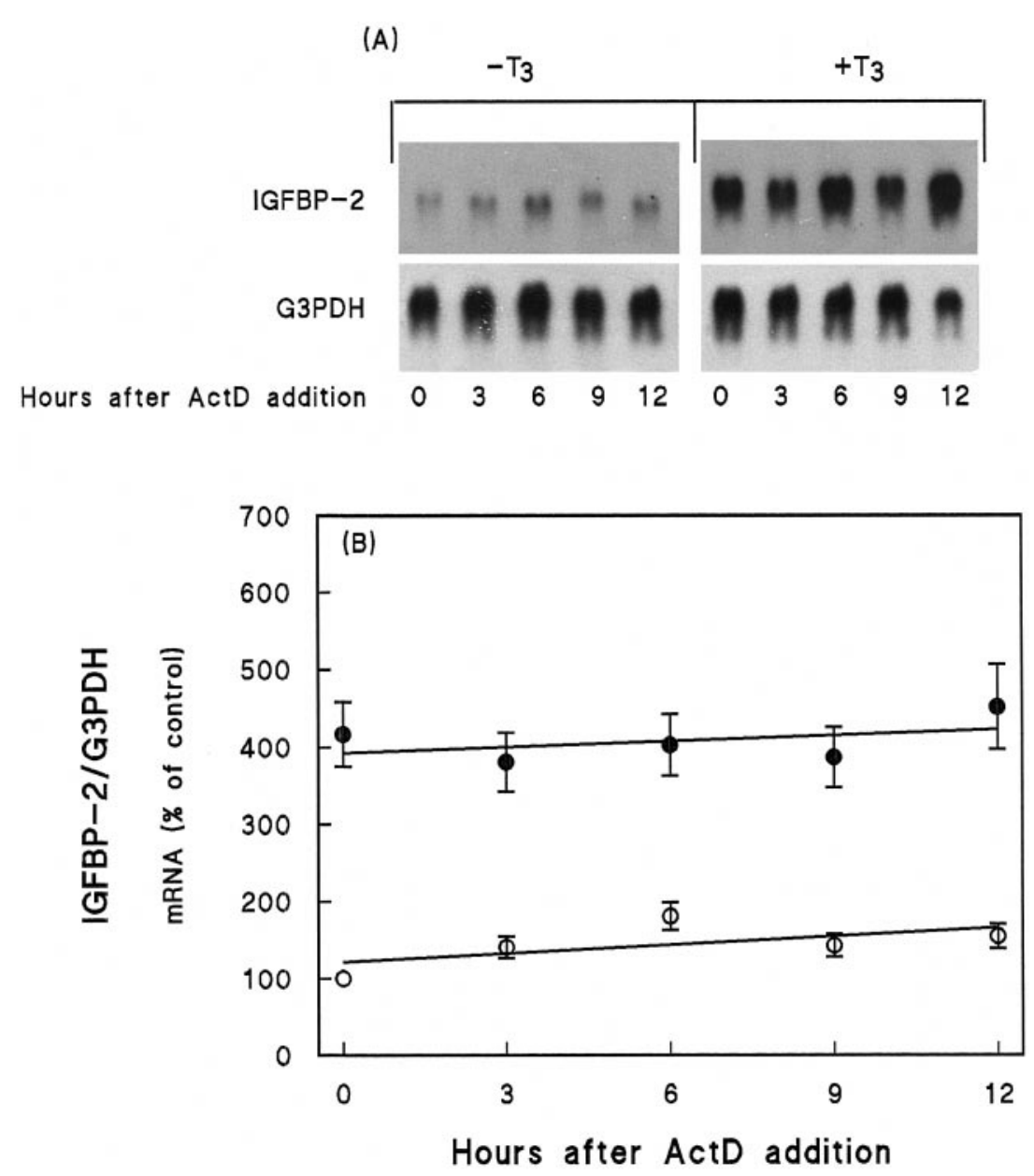

Figure 5 IGFBP-2 mRNA stability in hypothyroid rat hepatocytes cultured for $12 \mathrm{~h}$ (time 0 ) in the absence $(-)$ or presence $(+)$ of $10^{-6} \mathrm{M} \mathrm{T}_{3}$ and then exposed to $5 \mu \mathrm{g} / \mathrm{ml}$ actinomycin D (ActD) for different durations of time without a change of medium. (A) Representative autoradiogram of Northern blots showing $1.5 \mathrm{~kb}$ IGFBP-2 and $1.3 \mathrm{~kb}$ G3PDH mRNAs. (B) Densitometric quantification of Northern blots after normalization to $\mathrm{G} 3 \mathrm{PDH} .+\mathrm{T}_{3},-\mathrm{T}_{3}, \bigcirc$. Results are expressed as percentage of control (mean \pm S.E.M.; $n=3)$.

IGFBP-2 peptide production also was stimulated in $\mathrm{T}_{3^{-}}$ treated cells.

The effect of $\mathrm{T}_{3}$ on IGFBP-2 mRNA appeared to be independent of ongoing protein synthesis, as it was not abolished by the protein synthesis inhibitors, cycloheximide or anisomycin. The finding that the overall amount of IGFBP-2 transcript was greater in cells treated with cycloheximide or anisomycin could suggest the existence of a labile repressor protein that disappears when protein synthesis is blocked. However, direct evidence for the existence of such a protein is lacking.

The increase in IGFBP-2 mRNA steady state levels in $\mathrm{T}_{3}$-treated cells could be due to enhanced transcription of the gene, greater stability of the transcript, or both. In order to clarify these points, we tested the effect of the transcription inhibitor, actinomycin D, on IGFBP-2 mRNA abundance. Our results suggest a transcriptional regulation of the IGFBP-2 gene by $\mathrm{T}_{3}$ : when hepatocytes were treated with the hormone along with actinomycin $\mathrm{D}$ to block gene transcription, the stimulation of IGFBP-2 expression was abolished. Moreover, when actinomycin D was used in order to evaluate the IGFBP-2 mRNA half-life, the message showed stable levels both in $\mathrm{T}_{3^{-}}$ treated and in control cells, and no decay of the signal was apparent, so that a stabilizing effect of $T_{3}$ on IGFBP-2 mRNA seems unlikely.

The presence of a thyroid hormone response element in the promoter region of the rat IGFBP-2 gene has not been documented, but a specific stimulation of IGFBP-2 expression by $\mathrm{T}_{3}$ in osteoblasts has been observed (Schmid 
(A)

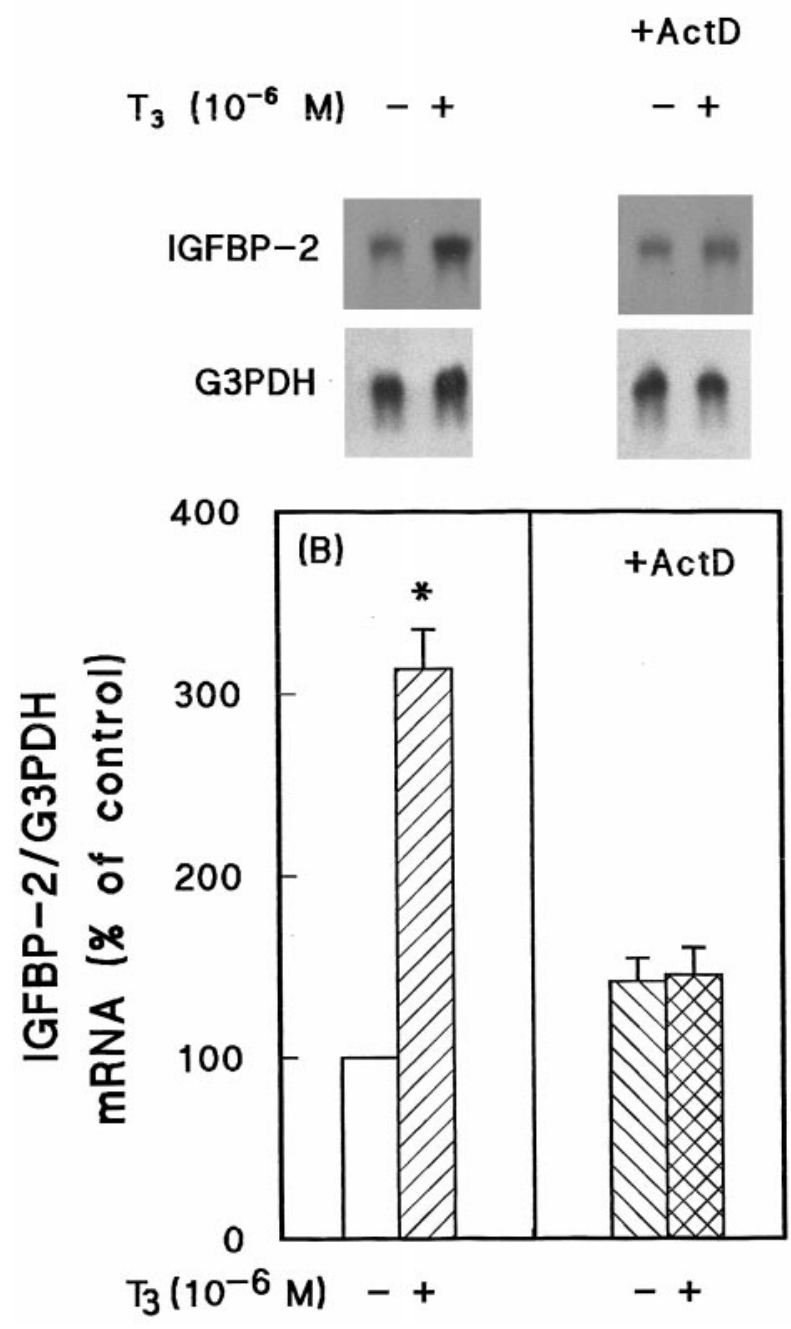

Figure 6 Effect of $\mathrm{T}_{3}$ on IGFBP-2 mRNA levels in hypothyroid rat hepatocytes cultured for $12 \mathrm{~h}$ with $(+)$ or without $(-) 10^{-6} \mathrm{M} \mathrm{T}_{3}$ in the presence $(+)$ or absence $(-)$ of actinomycin $\mathrm{D}(\mathrm{ActD})$ $(5 \mu \mathrm{g} / \mathrm{ml})$. (A) Representative autoradiogram of Northern blots showing $1.5 \mathrm{~kb}$ IGFBP-2 and $1.3 \mathrm{~kb}$ G3PDH mRNAs. (B) Densitometric quantification of Northern blots after normalization to G3PDH. Results are expressed as percentage of control ( $\square$ ) (mean \pm S.E.M.; $n=3$ ). ${ }^{*} P<0 \cdot 001$ compared with control.

et al. 1992a). Other hormonal factors, also, such as retinoic acid and dexamethasone, which act via nuclear receptors belonging to the steroid/thyroid receptor superfamily, have been reported to regulate IGFBP-2 expression in different cells (Schmid et al. 1992b, Ernst \& White 1996). However, the dominant regulator of IGFBP-2 mRNA levels in hepatocytes is considered to be insulin. When added to primary cultures of liver cells, insulin strongly decreases IGFBP-2 mRNA levels (Böni-Schnetzler et al. 1990). This result was also confirmed in our hepatocyte
(A)
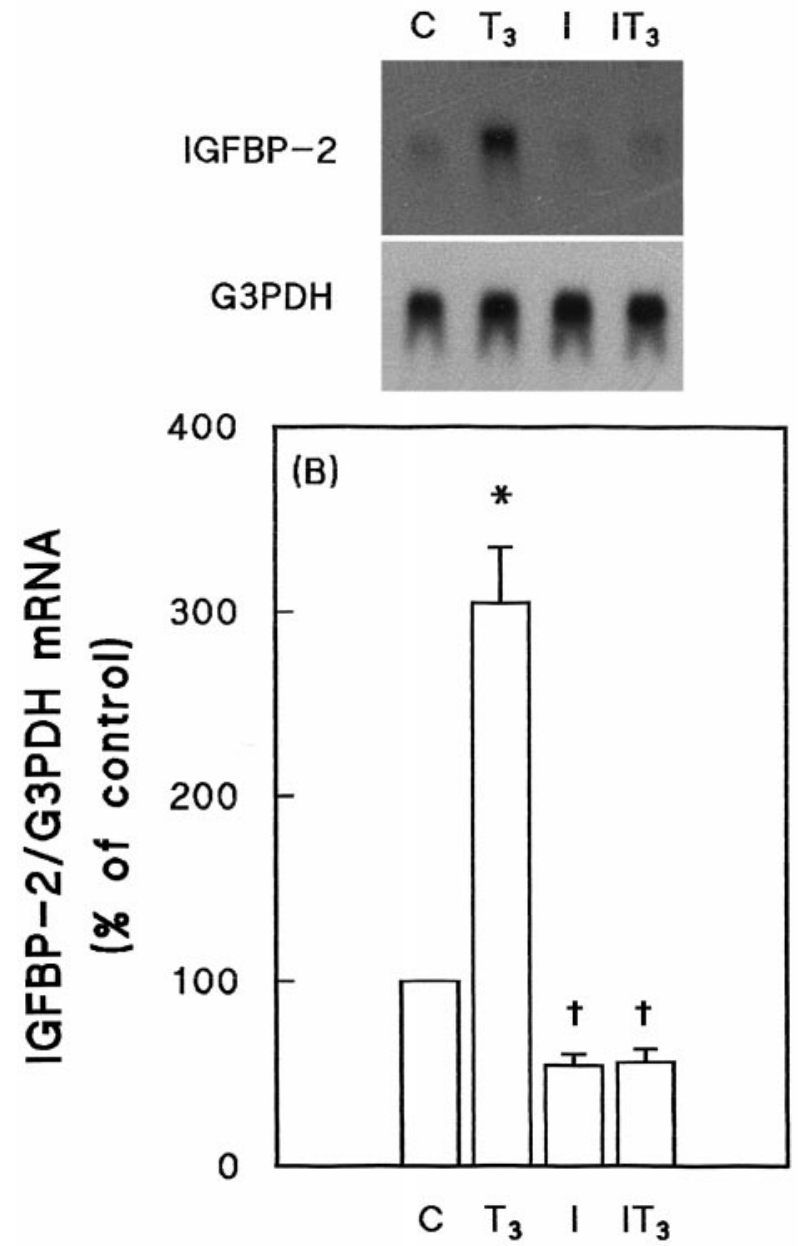

Figure 7 Effect of insulin (I) $\left(10^{-8} \mathrm{M}\right)$ on IGFBP-2 mRNA levels in hypothyroid rat hepatocytes cultured for $12 \mathrm{~h}$ in the absence or presence of $10^{-6} \mathrm{M} \mathrm{T}_{3}$. (A) Representative autoradiograms of Northern blots showing $1.5 \mathrm{~kb}$ IGFBP-2 and $1.3 \mathrm{~kb}$ G3PDH mRNAs. (B) Densitometric quantification of Northern blots after normalization to G3PDH. Results are expressed as percentage of control (C) (mean \pm S.E.M.; $n=3$ ). ${ }^{*} P<0 \cdot 003,+P<0 \cdot 05$ compared with control.

cultures from hypothyroid rats. We have demonstrated, in addition, that the inhibitory effect of insulin is dominant over the action of $\mathrm{T}_{3}$ : when both hormones are present in hepatocyte culture medium, the stimulatory effect of $\mathrm{T}_{3}$ on IGFBP-2 expression is suppressed.

The finding that the abundance of IGFBP- 2 mRNA is high in hepatocytes from hypothyroid rats and that $T_{3}$ directly increases it even more indicates that the increase in hepatic IGFBP-2 transcript levels observed in hypothyroidism is not related directly to decreased thyroid hormone levels, but to other possible alterations associated with hypothyroidism. With our in vivo experiments, we 
Table 1 Serum $\mathrm{T}_{3}$ and $\mathrm{T}_{4}$ concentrations in control, hypothyroid and $T_{3}$-treated rats. For details of treatments see Materials and Methods. Values are means \pm S.E.M. $(n=4)$

\begin{tabular}{|c|c|c|}
\hline & $\begin{array}{l}\text { Serum } \mathbf{T}_{3} \\
(\mathrm{ng} / \mathrm{ml})\end{array}$ & $\underset{(\mathrm{ng} / \mathrm{ml})}{\text { Serum }_{\mathbf{4}}}$ \\
\hline \multicolumn{3}{|l|}{ Treatment } \\
\hline Control & $0.53 \pm 0.03$ & $52 \cdot 56 \pm 1 \cdot 33$ \\
\hline PTU & $<0 \cdot 35^{* * *}$ & $<4$ \\
\hline $\mathrm{PTU}+\mathrm{T}_{3}$ & $4 \cdot 40 \pm 0.98 \dagger$ & $<4$ \\
\hline $\mathrm{T}_{3}$ & $2 \cdot 03 \pm 0 \cdot 49^{*}$ & $<4$ \\
\hline
\end{tabular}

$\dagger P<0 \cdot 02,{ }^{*} P<0 \cdot 04,{ }^{* * *} P<0 \cdot 001$ compared with control.

have demonstrated that $\mathrm{T}_{3}$ treatment of hypothyroid rats decreases hepatic IGFBP-2 transcript and serum IGFBP-2 levels to about $50 \%$ of those in hypothyroid rats. Moreover, when $\mathrm{T}_{3}$ was given to control animals, a modest but reproducible signal was detectable in the liver and a significant increase in IGFBP-2 concentration was measured in serum. Only the latter result is in agreement with our observations in vitro, demonstrating a direct stimulation of hepatic IGFBP-2 production by $\mathrm{T}_{3}$.

The possibility that PTU may have a thyroid hormoneindependent effect on IGFBP-2 expression seems unlikely

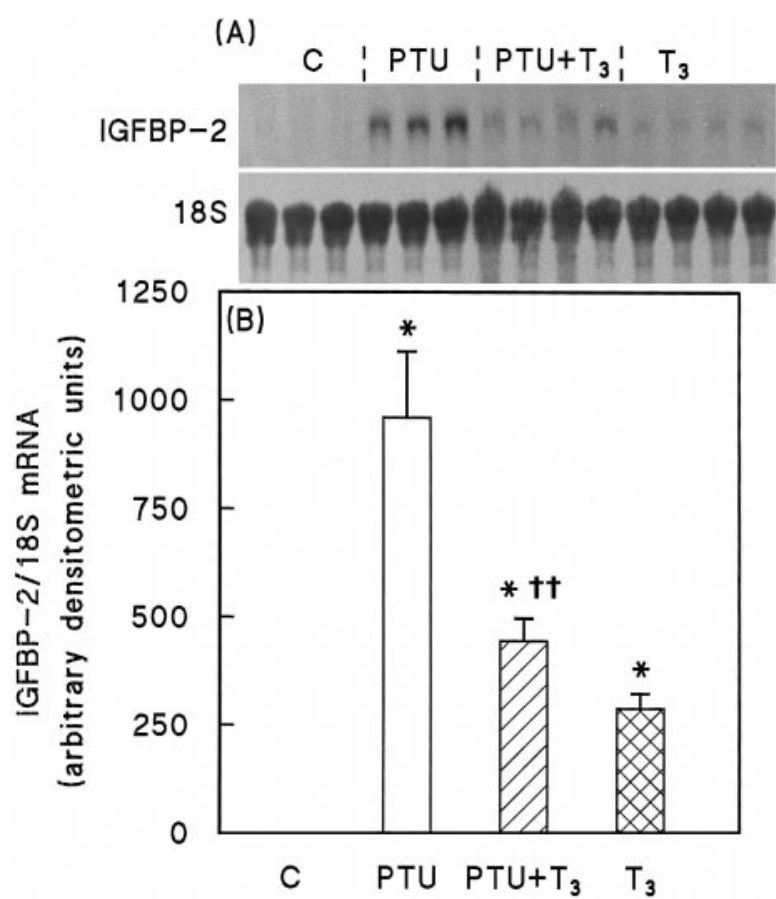

Figure 8 Effect of PTU and $T_{3}$ administration on IGFBP-2 mRNA levels in rat liver. The animals were treated as described in Materials and Methods. (A) Representative autoradiograms of Northern blots showing $1.5 \mathrm{~kb}$ IGFBP-2 mRNA and $1.9 \mathrm{~kb} 18 \mathrm{~S}$ rRNA. (B) Densitometric quantification of Northern blots after normalization to $18 \mathrm{~S}$. The signal in control (C) rats was undetectable and taken as 0 . Values are the means \pm S.E.M. $(n=3)$. ${ }^{*} P<0.001$ compared with control; $\dagger+P<0.01$ compared with PTU.
Table 2 Serum IGFBP-2 concentrations in control, hypothyroid and $\mathrm{T}_{3}$-treated rats. For details of treatments see Materials and Methods. Values are means \pm S.E.M. $(n=4)$

\section{Serum IGFBP-2}

$(\mathrm{ng} / \mathrm{ml})$

Treatment
Control
PTU
PTU $+\mathrm{T}_{3}$
$\mathrm{~T}_{3}$

$$
\begin{aligned}
& 136 \pm 11 \cdot 37 \\
& 280 \pm 16 \cdot 79^{* *} \\
& 162 \pm 11 \cdot 40^{*, * *} \\
& 151 \pm 13 \cdot 59^{* *}
\end{aligned}
$$

${ }^{*} P<0.04$ compared with PTU; ${ }^{* *} P<0.01$ compared with control.

as, when the drug was added to the culture medium of hepatocytes isolated from euthyroid animals, no direct effect on IGFBP-2 mRNA levels was apparent. Moreover,

(A)

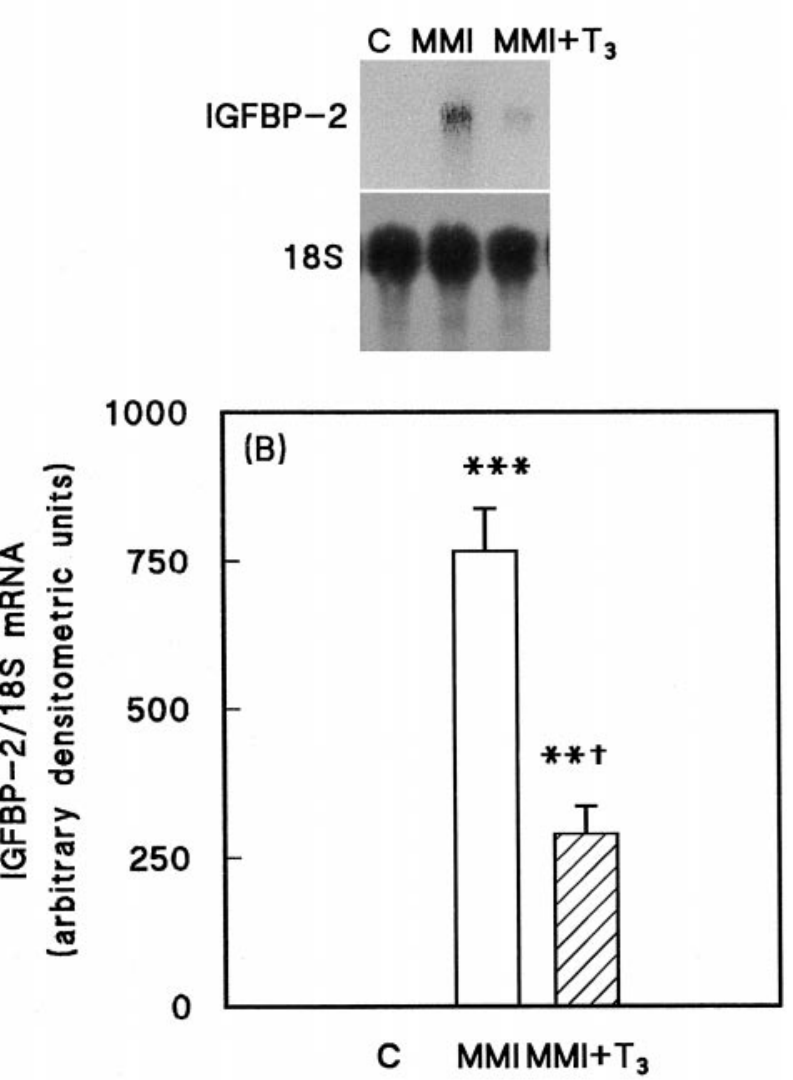

Figure 9 Effect of $\mathrm{MMI}$ administration and $\mathrm{T}_{3}$ replacement on IGFBP-2 mRNA levels in rat liver. The animals were treated as described in Materials and Methods. (A) Representative autoradiograms of Northern blots showing $1.5 \mathrm{~kb}$ IGFBP-2 mRNA and $1.9 \mathrm{~kb} 18 \mathrm{~S}$ rRNA. (B) Densitometric quantification of Northern blots after normalization to $18 \mathrm{~S}$. The signal in control (C) rats was undetectable and taken as 0 . Values are the means \pm S.E.M. $(n=3)$. $+P<0 \cdot 05,{ }^{* *} P<0 \cdot 001$ compared with control; ${ }^{* *} P<0 \cdot 01$ compared with MMI. 
with our in vivo experiments, we demonstrated that not only PTU- but also MMI-induced hypothyroidism was associated with enhanced expression of hepatic IGFBP-2. Therefore, the increase in IGFBP-2 expression may be due to secondary effects of hypothyroidism. As insulin is considered to be a dominant negative regulator of IGFBP-2 production by hepatocytes, and given the results of our in vitro experiments demonstrating that the inhibitory effect of insulin suppresses the stimulation of IGFBP-2 expression by $T_{3}$, we suggest that the effects observed in vivo could be due to an interplay between insulin and thyroid hormone. In vivo experiments indicate that hepatic IGFBP-2 message is preferentially increased in conditions of mild insulopenia, such as after hypophysectomy and fasting (Ooi et al. 1990, Tseng et al. 1992). Experimental hypothyroidism also represents a condition of insulin deficiency: plasma concentrations of insulin in hypothyroid rats have been reported to be reduced (Jolin et al. 1970, Doong et al. 1997) and peak plasma insulin responses to an intraperitoneal glucose load are lower in hypothyroid than in euthyroid rats (Jolin \& Montes 1974). Also, in our PTU-treated rats we have confirmed a reduced tolerance to i.p. injection of glucose (not shown), similar to the findings of Jolin \& Montes (1974). Even if the metabolic alterations associated with hypothyroidism are complex, the insulin deficiency could give a clue to explain, at least in part, the increase in hepatic IGFBP-2 message in PTU-treated rats. Moreover, it can be suggested that changes in nutrient intake and protein metabolism might play a role in the regulation of hepatic IGFBP-2 expression in hypothyroidism.

If not much is known about the factors that regulate hepatic IGFBP-2 expression in vivo, even less is understood concerning its physiological role. Mice lacking IGFBP-2 by targeted gene disruption are reported to be normal (Wood et al. 1993). IGFBP-2 appears to inhibit IGF actions, particularly those of IGF-II, although in certain specific cell types it can be a modest stimulator of IGF-I action (Jones \& Clemmons 1995). In general, the IGFBP family provides a remarkably versatile regulatory system for the IGFs and the factors capable of modulating IGFBP expression could in turn regulate IGF actions.

In conclusion, this study has demonstrated a direct stimulation of hepatic IGFBP-2 expression by thyroid hormone although, in vivo, other factors, such as insulin, appear to be involved in the regulation of hepatic IGFBP-2 in different thyroid status.

Taken together with our previous data (Demori et al. 1997), the results presented in this paper provide further evidence that thyroid hormone interacts with the hepatic IGF system directly at the level of IGFBPs, and support a role for a thyroid hormone-IGF axis.

\section{Acknowledgements}

The authors are indebted to Prof. G Gallo and A Voci for their participation in some of the experiments and to $\mathrm{V}$
Capicchioni for excellent technical assistance. We thank Dr A Barreca for help with IGFBP-2 RIA measurements. This work was supported by a grant from MURST, Rome, Italy.

\section{References}

Albiston AL \& Herington AC 1992 Tissue distribution and regulation of insulin-like growth factor (IGF)-binding protein-3 messenger ribonucleic acid (mRNA) in the rat: comparison with IGF-I mRNA expression. Endocrinology 130 497-502.

Arany E, Strain AJ, Hube MJ, Phillips ID \& Hill DJ 1993 Interactive effects of nutrients and hormones on the expression of insulin-like growth factor binding protein-1 (IGFBP-1) mRNA and peptide, and IGF I release from isolated adult rat hepatocytes. Journal of Cellular Physiology 155 426-435.

Barreca A, Voci A, Minuto F, de Marchis M, Cecchelli E, Fugassa E, Giordano G \& Gallo G 1992 Effect of epidermal growth factor on insulin-like growth factor-I (IGF-I) and IGF-binding protein synthesis by adult rat hepatocytes. Molecular and Cellular Endocrinology 84 119-126.

Böni-Schnetzler M, Binz K, Mary J-L, Schmid C, Schwander J \& Froesch ER 1989 Regulation of hepatic expression of IGF-I and fetal IGF binding protein mRNA in streptozotocin-diabetic rats. FEBS Letters 251 253-256.

Böni-Schnetzler M, Schmid C, Mary J-L, Zimmerli B, Meier PJ, Zapf J, Schwander J \& Froesch ER 1990 Insulin regulates the expression of the insulin-like growth factor binding protein 2 mRNA in rat hepatocytes. Molecular Endocrinology 4 1320-1326.

Brown AL, Chiariotti L, Orlowski CC, Mehlman T, Burgess WH, Ackerman EJ, Bruni CB \& Rechler MM 1989 Nucleotide sequence and expression of a cDNA clone encoding a fetal rat binding protein for insulin-like growth factor. Journal of Biological Chemistry $2645148-5154$.

Chan Y-L, Gutell R, Noller HF \& Wool IG 1984 The nucleotide sequence of a rat $18 \mathrm{~S}$ ribosomal ribonucleic acid gene and a proposal for the secondary structure of $18 \mathrm{~S}$ ribosomal ribonucleic acid. Journal of Biological Chemistry 259 224-230.

Chomczynski P \& Sacchi N 1987 Single-step method of RNA isolation by acid guanidinium thiocyanate-phenol-chloroform extraction. Analytical Biochemistry 162 156-159.

Cook D, Tolman KG \& Gray P 1983 The influence of thyroid hormones and propylthiouracil on salicylate hepatotoxicity in monolayer cell cultures. Biochemical Pharmacology 32 1454-1456.

Demori I, Bottazzi C, Voci A, Gallo G, Scharf J-G \& Fugassa E 1997 Tri-iodothyronine increases insulin-like growth factor binding protein-4 expression in rat hepatocytes. Journal of Endocrinology 154 155-165.

Donovan SM, Oh Y, Pham H \& Rosenfeld RG 1989 Ontogeny of serum insulin-like growth factor binding proteins in the rat. Endocrinology 125 2621-2627.

Doong M-L, Wang JW-C, Chung S-C, Liu J-Y, Hwang C, Hwang C-Y, Day CH, Liu Y-F, Young T-K, Ho LL-T \& Wang PS 1997 Regulation of thyroid hormones in the secretion of insulin and gastric inhibitory polypeptide in male rats. Metabolism 46 154-158.

Ernst CW \& White ME 1996 Hormonal regulation of IGF-binding protein-2 expression in proliferating $\mathrm{C}_{2} \mathrm{C}_{12}$ myoblasts. Journal of Endocrinology 149 417-429.

Froesch ER, Schmid C, Schwander J \& Zapf J 1985 Actions of insulin-like growth factors. Annual Review of Physiology 47 443-467.

Fugassa E, Gallo G, Voci A \& Cordone A 1983 RNA synthesis in primary cultures of adult rat hepatocytes. In Vitro 19 299-306.

Jolin T \& Montes A 1974 The different effects of thyroidectomy, $\mathrm{KClO}_{4}$ and propylthiouracil on insulin secretion and glucose uptake in the rat. Endocrinology 94 1502-1507.

Jolin T, Morreale de Escobar G \& Escobar del Rey F 1970 Differential effects in the rat of thyroidectomy, propylthiouracil and 
other goitrogens on plasma insulin and thyroid weight. Endocrinology 87 99-110.

Jones JI \& Clemmons DR 1995 Insulin-like growth factors and their binding proteins: biological actions. Endocrine Review 16 3-34.

Lund PK, Moats-Staats BM, Hynes MA, Simmons JG, Jansen M, D’Ercole AJ \& Van Wyk JJ 1986 Somatomedin-C/insulin-like growth factor-I and insulin-like growth factor-II mRNA in rat fetal and adult tissues. Journal of Biological Chemistry 261 14539-14544.

Margot JB, Binkert C, Mary J-L, Landwehr J, Heinrich G \& Schwander J 1989 A low molecular weight insulin-like growth factor binding protein from rat: cDNA cloning and tissue distribution of its messenger RNA. Molecular Endocrinology 3 1053-1060.

Mariash CN \& Oppenheimer JH 1983 Interrelationship of triiodothyronine concentration, metabolism, protein binding, and nuclear occupancy in the induction of malic enzyme by cultured adult rat hepatocytes. Endocrinology 112 80-85.

Messina JL 1991 Inhibition and stimulation of c-myc gene transcription by insulin in rat hepatoma cells: insulin alters the intragenic pausing of c-myc transcription. Journal of Biological Chemistry 266 17995-18001.

Näntö-Salonen K, Glasscock GF \& Rosenfeld RG 1991 The effects of thyroid hormone on insulin-like growth factor (IGF) and IGF-binding protein (IGFBP) expression in the neonatal rat: prolonged high expression of IGFBP-2 in methimazole-induced congenital hypothyroidism. Endocrinology 129 2563-2570.

Näntö-Salonen K, Muller HL, Hoffman AR, Vu TH \& Rosenfeld RG 1993 Mechanism of thyroid hormone action on the insulin-like growth factor system: all thyroid hormone effects are not growth hormone mediated. Endocrinology 132 781-788.

Ooi GT, Orlowski CC, Brown AL, Becker RE, Unterman TG \& Rechler MM 1990 Different tissue distribution and hormonal regulation of messenger RNAs encoding rat insulin-like growth factor-binding protein-1 and -2. Molecular Endocrinology 4 321-328.
Orlowski CC, Brown AL, Ooi GT, Yang YW-H, Tseng LY-H \& Rechler MM 1990 Tissue, developmental, and metabolic regulation of mRNA encoding a rat insulin-like growth factor binding protein (rIGFBP-2). Endocrinology 126 644-652.

Rechler MM 1993 Insulin-like growth factor binding proteins. Vitamins and Hormones 47 1-114.

Rodriguez-Arnao J, Miell J,Thomas M, McGregor AM \& Ross RJM 1994 Changes in hepatic insulin-like growth factor-binding proteins-1, -2 and -3 mRNA levels in rats with altered thyroid status. Journal of Endocrinology 140 251-255.

Sambrook J, Fritsch EF \& Miniatis T 1989 Molecular Cloning: A Laboratory Manual, edn 2. Cold Spring Harbor, NY: Cold Spring Harbor Laboratory Press.

Schmid C, Schläpfer I, Futo E, Waldvogel M, Schwander J, Zapf J \& Froesch ER 1992a Triiodothyronine $\left(\mathrm{T}_{3}\right)$ stimulates insulin-like growth factor (IGF)-I and IGF binding protein (IGFBP)-2 production by rat osteoblasts in vitro. Acta Endocrinologica 126 $467-473$.

Schmid C, Schläpfer I, Waldvogel M, Meier PJ, Schwander J, Böni-Schnetzler M, Zapf J \& Froesch ER $1992 b$ Differential regulation of insulin-like growth factor binding protein (IGFBP)-2 mRNA in liver and bone cells by insulin and retinoic acid in vitro. FEBS Letters 303 205-209.

Tseng LY-H, Ooi GT, Brown AL, Straus DS \& Rechler MM 1992 Transcription of the insulin-like growth factor binding protein-2 gene is increased in neonatal and fasted adult rat liver. Molecular Endocrinology 6 1195-1201.

Wood TL, Rogler L, Streck RD, Cerro J, Green B, Grewal A \& Pintar JE 1993 Targeted disruption of IGFBP-2 gene. Growth Regulation 3 5-8.

Received 3 August 1998

Revised manuscript received 4 January 1999

Accepted 29 January 1999 